\title{
Effective use of CT by surgeons in acute appendicitis diagnosis
}

\author{
Mehmet Mahir Fersahoğlu, M.D., ㄴ) Hüseyin Çiyiltepe, M.D., ๑ Anıl Ergin, M.D., \\ Ayşe Tuba Fersahoğlu, M.D., (i) Nuriye Esen Bulut, M.D., A- Ahmet Başak, M.D., \\ (1) Bora Karip, M.D., () Birol Ağca, M.D.
}

Department of General Surgery, Fatih Sultan Mehmet Training and Research Hospital, İstanbul-Turkey

\begin{abstract}
BACKGROUND: Acute appendicitis (AA) still maintains its prominence among general surgical emergencies, and the risk of developing $A A$ is $8.6 \%$ for men and $6.7 \%$ for women. The clinical diagnosis of acute appendicitis has a rate of approximately $20 \%$ false positive and false-negative. Ultrasound (US) and Computed Tomography (CT) are the imaging methods most utilized in this field. The present study aims to determine the relationship between the evaluation results of the clinician who examined the patient and the radiologist's evaluation in the evaluation of cross-sectional imaging tests for the diagnosis of acute appendicitis.
\end{abstract}

METHODS: In this study, the records of 1891 patients who underwent an appendectomy in the General Surgery Clinic of Fatih Sultan Mehmet Training and Research Hospital between January 2010 and 2017 were reviewed retrospectively. From the file of the patients who underwent appendectomy with acute appendicitis and whose appendix was reported as normal in CT results, clinical examination findings of the patient in the emergency department and CT evaluation results of the relevant surgeon (Compatible with acute appendicitis, normal appendix or appendix could not be visualised) were recorded.

RESULTS: Of the 189I patients, who underwent appendectomy on suspicion of acute appendicitis, I478 had CT scans for diagnosis and 145 were reported as normal by radiologists. In the evaluations by surgeons of these CT results all reported as normal by radiologists, 105 (\%) 72,4) were compatible with acute appendicitis, while 18 (I2.4\%) were considered normal. In 22 (I5.2\%) patients, appendix could not be the visualized by surgeons. $70.0 \%$ of the cases with Lymphoid hyperplasia - fibrous obliteration pathology result; $73.8 \%$ of the cases with acute appendicitis; $75.6 \%$ of those with phlegmonousappendicitis and $64.0 \%$ of those with gangrenous/perforated appendicitis were diagnosed as appendicitis by $\mathrm{CT}$ evaluation performed by a general surgeon.

CONCLUSION: Diagnostic accuracy rates increase significantly when the CT results are interpreted by the physician performing the clinical evaluation of the patient. The chance of reaching the correct diagnosis will increase with gaining the ability to interpret abdominal cross-sectional imaging techniques during general surgery specialty training.

Keywords: Acute abdomen; acute appendicitis; computed tomography.

\section{INTRODUCTION}

Acute appendicitis (AA) still maintains its prominence among general surgical emergencies and the risk of developing $A A$ is $8.6 \%$ for men and $6.7 \%$ for women. ${ }^{[1]}$ It was more common in the second and third decades. ${ }^{[2]}$ Although in recent years, antibiotherapy has been an alternative to surgery, especially for uncomplicated appendicitis; the possibility of the development of variances like perforation and gangrene that complicate appendicitis and intraabdominal abscess and sepsis secondary to those prioritize surgery as a treatment option. However, accuracy rates between $60-90 \%$ by conventional diagnostic methods and, to be clearer, high negative appendectomy rates come to the fore. The clinical diagnosis of acute appendicitis has a rate of approximately $20 \%$ false positive and false-negative. ${ }^{[3,4]}$ This group of patients consists

Cite this article as: Fersahoğlu MM, Çiyiltepe H, Ergin A, Fersahoğlu AT, Bulut NE, Başak A, et al. Effective use of CT by surgeons in acute appendicitis diagnosis. Ulus Travma Acil Cerrahi Derg 2021;27:43-49.

Address for correspondence: Mehmet Mahir Fersahoğlu, M.D.

Fatih Sultan Mehmet Eğitim ve Araştırma Hastanesi, Genel Cerrahi Kliniği, İstanbul, Turkey

Tel: +90 216 - 5783000 E-mail: fersahoglu@yahoo.com 
of the group difficult to diagnose due to uncertain clinical findings and/or laboratory test results..$^{[5,6]}$

Ovarian cyst, ectopic pregnancy, tubal abscess, gastrointestinal diverticulitis, intussusception, cholecystitis, intestinal inflammation, mesenteric adenitis, renal/ureteral stone, hydronephrosis, pyelonephritis, hydroureter should be kept in mind in the differential diagnosis. ${ }^{[7]}$ In this current situation, which requires these clinical pictures to be carefully scrutinized, many methods ranging from specific physical examination findings to laboratory markers, to many developed scorings and even to a combination of these methods have been tried to lower the rate of negative appendectomy. The increase in the number of diagnostic parameters introduces problems in accessibility, ease of use, cost-effectiveness and time. Ultrasound (US) and Computed Tomography (CT) are the imaging methods most utilized in this field. ${ }^{[2]}$

Many diagnostic procedures can be time-consuming, which may allow for uncomplicated appendicitis cases to become complicated in that duration and lead to an increase in morbidity and mortality. Therefore, the cost-effective modalities that will easily lead to accurate diagnosis in a short time are of importance. ${ }^{[8]}$

The present study aims to investigate the relationship between the evaluation results of the clinician who examined the patient and the radiologist's evaluation in the evaluation of cross-sectional imaging tests for the diagnosis of acute appendicitis.

\section{MATERIALS AND METHODS}

\section{Patient Inclusion}

Following approval from the local ethics committee of Fatih Sultan Mehmet Training and Research Hospital (decision no: 2934) the records of 1891 patients who underwent appendectomy between January 2010 and 2017 were retrospectively reviewed. Demographic characteristics, examination, laboratory and imaging results and histopathological examinations were recorded.

Patients with acute appendicitis or complications reported on imaging results (US and CT) were not included in the study group.

From the file of the patients who underwent appendectomy with acute appendicitis and whose appendix was reported as normal in CT results, clinical examination findings of the patient in the emergency department and CT evaluation results of the relevant surgeon (Compatible with acute appendicitis, normal appendix or appendix could not be visualised) were recorded.

CT examinations were performed using GE Healthcare Optima CT 660128 Multislice device. In the CT assessment per- formed by the surgeon:

I) Thicker than normal and edematous appearance of the appendix

2) Hyperdense appearance in lumen (Appendicolite)

3) Blind terminated, tubular structure

4) One or more of the criteria for contamination in the periapendicular region were accepted as meaningful findings for appendicitis.

\section{Statistical Reviews}

NCSS (NumberCruncher Statistical System) 2007 (Kaysville, Utah, USA) was used for statistical analysis. Descriptive statistical methods (Mean, Standard Deviation, Median, Frequency, Ratio, Minimum, Maximum) were used to evaluate the study data. The Kruskal Wallis test was used in the comparison of groups of three and more without normal distribution. In comparison of qualitative data, Pearson Chisquare test, Fisher-Freeman-Halton test and McNemar fit test were used. The significance level was accepted to be $\mathrm{p}<0.05$.

Sensitivity: It is the ability of the test to identify patients amongst real patients.

Specificity: It is the ability of the test to determine the intacts amongst the real intacts.

Positive Estimation Value: It is a measure of the conditional probability of the fact that the case is actually ill when the test gives a positive (patient) result.

Negative Estimation Value: It is the possibility of the case being actually healthy when the test gives a negative (robust) result.

\section{RESULTS}

Between January 2010 and 2017, I891 patients underwent appendectomy for suspected acute appendicitis in the general surgery clinic of Fatih Sultan Mehmet Training and Research Hospital. Of these patients, 1478 had CT scans for diagnosis, and 145 were reported as normal by radiologists.

Table I. Distribution of demographic characteristics

\begin{tabular}{lc}
\hline Demographic characteristics & $\mathbf{n}(\%)$ \\
\hline Age (years) & \\
$\quad$ Min-Max (Median) & $17-80(26)$ \\
$\quad$ Mean \pm SD & $30.67 \pm \mid 3.16$ \\
Sex & \\
$\quad$ Male & $74(51.0)$ \\
Female & $71(49.0)$ \\
\hline
\end{tabular}

SD: Standard deviation. 
Of the 145 patients, $51.0 \%(n=74)$ were males and $49.0 \%$ $(n=7 I)$ were females and the mean age was $30.67 \pm 13.16$ (I7-80) (Table I).

Table 2. Computed tomography evaluations by general surgeons for cases detected as normal by radiologists

\begin{tabular}{lc}
\hline Computed tomography evaluation & $\mathbf{n}(\%)$ \\
\hline $\begin{array}{l}\text { General surgery } \\
\text { Non-visualisable }\end{array}$ & $22(15.2)$ \\
Computed tomography evaluation & \\
$\quad$ Not appendicitis & $18(12.4)$ \\
Appendicitis & $105(72.4)$ \\
\hline
\end{tabular}

CT evaluations were performed with Intravenous (IV) contrast in 99 (68.3\%) patients and without contrast in 46 ( $31.7 \%$ ) patients. In the evaluations by surgeons of these CT results all reported as normal by radiologists, 105 (72.4\%) were compatible with acute appendicitis, while 18 (12.4\%) were considered normal. In 22 (15.2\%) patients, appendix could not be visualized by surgeons (Table 2 ).

In Table 3, the results of CT evaluation by general surgeons were compared with demographic data, laboratory findings and CT noncontrast status of the patient. No statistically significant difference was detected between age, sex, CT contrast status, Leukocyte, Neutrophil, MPV, CRP, N/L and P/L measurements $(p>0.05)$.

Table 3. The results of CT evaluation by general surgeons were compared with demographic data, laboratory findings and $\mathrm{CT}$ noncontrast status of the patient

\section{CT result}

Appendicitis $(n=105) \quad$ Not appendicitis $(n=18) \quad$ Non-visualisable $(n=22)$

\section{Age (years)}

Min-Max (Mean)

Mean \pm SD

Sex

Female (\%)

Male (\%)

CT contrast status

Contrast present $(n=46)$

Contrast not present $(n=99)$

Leukocytes

Min-Max (Median)

Mean \pm SD

Neutrophile

Min-Max (Median)

Mean \pm SD

MPV

Min-Max (Median)

Mean \pm SD

CRP $(n=76)$

Min-Max (Median)

Mean \pm SD

Neutrophil/Lymphocyte

Min-Max (Median)

Mean \pm SD

Platelet/Lymphocyte

Min-Max (Median)

Mean \pm SD
$17-80(26)$

$30.83 \pm 13.16$

$50(47.6)$

55 (52.4)

$70(66,6)$

$35(33.4)$

4800-40500 (14100)

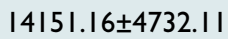

43.3-94.9 (78.5)

$76.77 \pm 10.01$

$5.4-11.4(7.6)$

$7.66 \pm 1.14$

0-30.5 (1.3)

$3.57 \pm 5.22$

$0.9-44.6(5.8)$

$7.44 \pm 6.11$

25.6-580 (I 19)

$141.82 \pm 77.36$
18-66 (3I)

$35.39 \pm 15.68$

$9(50.0)$

$9(50.0)$

II (6I.I)

7 (38.9)

10200-18200 (13600)

$13922.22 \pm 2690.16$

43.3-86.8 (78.2)

$72.50 \pm 13.63$

$6.6-\mid I .4(8.2)$

$8.41 \pm 1.48$

$0.1-26(I . I)$

II. $10 \pm 7.23$

$0.9-12.6(4.6)$

$5.05 \pm 3.45$

25.6-931.3 (I 10.8)

$197.29 \pm 279.32$
18-54 (24)

$26.05 \pm 9.49$

$12(54.5)$

10 (45.5)

18 (81.8)

4 (18.2)

0.299

10400-22300 (17500)

0.476

$162|4.29 \pm 470| .22$

$73.4-93.8$ (77.9)

$80.44 \pm 7.08$

7-9.5 (7.7)

0.303

$7.77 \pm 0.85$

$0.1-16.5(6.5)$

$7.40 \pm 7.02$

3.6-24.7 (5.9)

$8.89 \pm 7.30$

0309

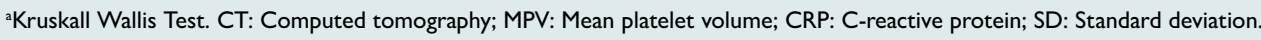

64.4-36I.4 (120.6)

$152.57 \pm 103.50$ 
$70.0 \%$ of the cases with Lymphoid hyperplasia-fibrous obliteration pathology result; $73.8 \%$ of the cases with acute appendicitis; $75.6 \%$ of those with phlegmonousappendicitis and $64.0 \%$ of those with gangrenous/perforated appendicitis were diagnosed as appendicitis by CT evaluation performed by general surgery (Table 4).

Evaluations made with only appendicitis and non-appendicitis cases and excluding the cases which could not have been visualised in the CT evaluation by a general surgeon; according to pathology results, nine cases were normal and 18 cases were normal according to $\mathrm{CT}$ evaluations. According to pathology results, II 4 cases were detected as appendicitis, while 105 cases were detected as appendicitis by CT evaluations.

Of the nine cases which were determined as normal by pathology results, only two were normal and seven were appendicitis according to CT evaluations by general surgeons. Of the II 4 cases determined as appendicitis according to the pathology results, 16 were normal and 98 were appendicitis according to CT evaluations by general surgeons. A statistically significant correlation between pathology and $C T$ evaluation results was determined $(p=0.093 ; p>0.05)$. Accordingly, the sensitivity was determined as $85.96 \%$, specificity as $22.22 \%$ and accuracy as $81.30 \%$. The positive estimation value was observed to be $93.33 \%$ and the negative predictive value to be $11.11 \%$.

Evaluations made including the cases which could not have been visualised in the CT evaluations by a general surgeon in the appendicitis group; according to the pathology results, 10 cases were found to be normal and 18 cases were normal according to CT evaluation of general surgery specialists. According to the pathology results, I 35 cases were appendicitis while 127 cases were appendicitis according to CT evaluations of general surgery specialists.

Of the 10 cases which were determined as normal by pathology results, only two were found to be normal and eight were appendicitis according to $\mathrm{CT}$ evaluations by general surgery specialists. Of the 135 cases determined as appendicitis according to the pathology results, 16 were normal and 119 were appendicitis according to $\mathrm{CT}$ evaluations by general surgery specialists. A statistically significant correlation between pathology and CT evaluation results was determined $(p=0.152 ; p>0.05)$. Accordingly, the sensitivity was determined as $85.15 \%$; specificity as $20.00 \%$ and accuracy as $83.45 \%$. The positive estimation value was observed to be $93.70 \%$ and the negative predictive value to be $1 \mathrm{I} .1 \mathrm{I} \%$.

Evaluations made including the cases which could not have been visualised in the CT evaluations by a general surgeon in the non-appendicitis group; according to the pathology results, 10 cases were normal and 40 cases were normal according to CT evaluation of general surgery specialists. According to the pathology results, 135 cases were appendicitis while 105 cases were appendicitis according to CT evaluations of general surgery specialists.

Of the 10 cases which were determined as normal by pathology results, only three were normal and seven were appendicitis according to $\mathrm{CT}$ evaluations by general surgeons. Of the 135 cases determined as appendicitis according to the pathology results, 37 were normal and 98 were appendicitis according to $C T$ evaluations by general surgeons. No statistically significant correlation between pathology and CT evaluation results by general surgeons was detected $(p=0.00 \mathrm{I} ; \mathrm{p}<0.0 \mathrm{I})$. Accordingly, the sensitivity was determined as $72.59 \%$, specificity as $30.00 \%$ and accuracy as $69.66 \%$. The positive estimation value was observed to be $93.33 \%$ and the negative predictive value to be $7.50 \%$.

\section{DISCUSSION}

In our study, it was seen that in the evaluation of imaging tests, such as CT for the diagnosis of acute appendicitis, the clinician examining the patient affects the $C T$ result in cases that were interpreted as normal by the radiologist.

Clinical evaluation is prominent in diagnosing acute appendicitis, and the most typical signs and symptoms are periumbilical pain migrating to the right lower quadrant, subfebrile fever, anorexia, and rebound in the right lower quadrant with increased leukocyte count. ${ }^{[9]}$ Clinical findings may be diminished in children and the elderly, or patients may have problems with expression. Thus, it may be difficult to diagnose

Table 4. Investigation of the relationship between general surgery evaluations and pathology results

\begin{tabular}{lcccc}
\hline & \multicolumn{3}{c}{ Pathology } \\
\cline { 2 - 5 } & $\begin{array}{c}\text { Lymphoid hyp.- } \\
\text { Fibrous obl. }(\mathbf{n = 1 0 )}\end{array}$ & $\begin{array}{c}\text { Acute appendicitis } \\
(\mathbf{n = 6 5 )}\end{array}$ & $\begin{array}{c}\text { Phlegmonousappendicitis } \\
(\mathbf{n = 4 5 )}\end{array}$ & $\begin{array}{c}\text { Gangranous/Perforated ap. } \\
(\mathbf{n}=\mathbf{2 5})\end{array}$ \\
\hline $\begin{array}{l}\text { CT evaluation, } \mathrm{n}(\%) \\
\text { Non-visualisable }\end{array}$ & $1(10.0)$ & $7(10.8)$ & $7(15,6)$ & $7(28.0)$ \\
Not appendicitis & $2(20.0)$ & $10(15.4)$ & $4(8,9)$ & $2(8.0)$ \\
Appendicitis & $7(70.0)$ & $48(73.8)$ & $34(75.6)$ & $16(64.0)$ \\
\hline
\end{tabular}


Table 5. Compliance of pathology results with CT evaluations

\begin{tabular}{|c|c|c|c|c|}
\hline & \multicolumn{3}{|c|}{ Pathology result } & \multirow[t]{2}{*}{ cp } \\
\hline & Not appendicitis & Appendicitis & Total & \\
\hline \multicolumn{5}{|c|}{ 'General surgery CT evaluation; n (\%) } \\
\hline Not appendicitis & $2(1.6)$ & $16(13)$ & $18(14,6)$ & 0.093 \\
\hline Appendicitis & $7(5.7)$ & $98(79.7)$ & $105(85.4)$ & \\
\hline Total & $9(7.3)$ & II 4 (92.7) & $123(100)$ & \\
\hline Sensitivity & 85.96 & & & \\
\hline Specificity & 22.22 & & & \\
\hline Positive estimation value & 93,33 & & & \\
\hline Negative estimation value & II.II & & & \\
\hline Accuracy & 81.30 & & & \\
\hline \multicolumn{5}{|c|}{${ }^{2}$ General surgery CT evaluation; $\mathrm{n}(\%)$} \\
\hline Not appendicitis & $2(1.4)$ & $16(11)$ & $18(12.4)$ & 0.152 \\
\hline Appendicitis & $8(5.5)$ & $119(82.1)$ & $127(87.6)$ & \\
\hline Total & $10(6.9)$ & $135(93.1)$ & $145(100)$ & \\
\hline Sensitivity & 88.15 & & & \\
\hline Specificity & 20.00 & & & \\
\hline Positive estimation value & 93.70 & & & \\
\hline Negative estimation value & II.II & & & \\
\hline Accuracy & 83.45 & & & \\
\hline \multicolumn{5}{|c|}{${ }^{3}$ General surgery CT evaluation; n (\%) } \\
\hline Not appendicitis & $3(2.1)$ & $37(25.5)$ & $40(27.6)$ & $0.001^{* *}$ \\
\hline Appendicitis & $7(4.8)$ & $98(67,6)$ & $105(72.4)$ & \\
\hline Total & $10(6.9)$ & $135(93.1)$ & $145(100)$ & \\
\hline Sensitivity & 72.59 & & & \\
\hline Specificity & 30.00 & & & \\
\hline Positive estimation value & 93.33 & & & \\
\hline Negative estimation value & 7.50 & & & \\
\hline Accuracy & 69.66 & & & \\
\hline
\end{tabular}

'Those who could not be visualised were not included in the assessment. ${ }^{2 n d}$ Those who could not be visualised were included in the appendicitis group. ${ }^{3}$ Those who could not be visualised were included in the group not appendicitis. ${ }^{M c N e m a r}$ Test ${ }^{* *} \mathrm{P}<0.01$. CT: Computed tomography.

acute appendicitis with clinical findings. Additional imaging tests are important in this patient group. ${ }^{[9]}$

In a study conducted by Teo et al., ${ }^{[10]}$ it was reported that differential diagnosis is more difficult in women, the probability of negative appendectomy is higher, and CT is particularly useful to help diagnose appendicitis in women.

With the use of imaging methods, such as the US, CT and $\mathrm{MRI}$, negative appendectomy rates have been reduced. In a study conducted by Parks and Schroeppel, it was seen that the negative appendectomy rate was $4.9 \%$ in the imaging group and $9.8 \%$ in the non-imaging group. ${ }^{\left[{ }^{\prime \prime}\right]}$

In their study, Ceydeli et al. ${ }^{[9]}$ reported that the best way to diagnose acute appendicitis is the timely evaluation of the symptoms and findings of the patients by an experienced surgeon on a patient basis and determining whether the patient needs a CT scan.

While appendicitis is a diagnosis based primarily on clinical findings, according to the guidelines of the American College of Radiology, CT is a key imaging method to evaluate adult patients with suspected appendicitis. ${ }^{[12]}$ The advantages of CT include its high accuracy, widespread usability, and ease of use, operator independence, cost-effectiveness, better evaluation of complications, and the ability to identify other causes of abdominal pain. ${ }^{[13,14]}$ However, there is radiation exposure. Although US does not carry any risk of radiation exposure like $\mathrm{CT}$, the quality of a US depends on the skills and experience of the radiologist and has a relatively low sensitivity and specificity. ${ }^{[15]}$ 
In their study, Patrick et al. ${ }^{[16]}$ relate the lack of a significant change in the negative appendectomy rates despite the increased use of CT in the diagnosis of acute appendicitis with that an examination by an experienced surgeon is the most valuable method for the diagnosis of acute appendicitis. According to Karabulut et al.,[17] $20 \%$ of patients are misdiagnosed with clinical findings and false-negative appendectomy is performed. Imaging examinations are often needed to confirm or exclude the diagnosis.

Patients admitted to the emergency department of our hospital with a preliminary diagnosis of acute appendicitis are evaluated by a general surgeon and then are scanned with abdominal CT, with or without contrast according to the patient's clinical condition. There is an occasional discrepancy between the $\mathrm{CT}$ results reported by the radiologist and the evaluations of surgeons. In this study, when CTs reported being normal by radiologists for acute appendicitis were evaluated by surgeons, $85.4 \%$ of patients were considered as acute appendicitis, and the pathology results of $93.3 \%$ of these patients were reported as appendicitis. We believe that this result arises from that radiologists evaluate CT images independently of the patient's anamnesis and laboratory and clinical examination findings. Presumably, the lack of knowledge regarding the patient's clinical information increased the radiological false negativity.

\section{Conclusion}

In the diagnosis of acute appendicitis, imaging methods are utilized along with clinical evaluation. However, diagnostic accuracy rates increase significantly when the CT results are interpreted by the physician performing the clinical evaluation of the patient. The chance of reaching the correct diagnosis will increase with gaining the ability to interpret abdominal cross-sectional imaging techniques during general surgery specialty training.

Ethics Committee Approval: Approved by the local ethics committee (decision number: 2934).

Peer-review: Internally peer-reviewed.

Authorship Contributions: Concept: M.M.F., A.E.; Design: H.Ç., A.T.F.; Supervision: A.B.; Resource: B.K.; Materials: B.A.; Data: M.M.F.; Analysis: A.E., A.T.F.; Literature search: M.M.F., B.K.; Writing: M.M.F., H.Ç.; Critical revision: B.A., N.E.B.

Conflict of Interest: None declared.

Financial Disclosure: The authors declared that this study has received no financial support.

\section{REFERENCES}

1. Addiss DG, Shaffer N, Fowler BS, Tauxe RV. The epidemiology of appendicitis and appendectomy in the United States. Am J Epidemiol 1990;132:910-25. [CrossRef]

2. Rybkin AV, Thoeni RF. Current concepts in imaging of appendicitis. Radiol Clin North Am 2007;45:411-vii. [CrossRef]

3. Ramirez JM, Deus J. Practical score to aid decision making in doubtful cases of appendicitis. Br J Surg 1994;81:680-3. [CrossRef]

4. Lewis FR, Holcroft JW, Boey J, Dunphy E. Appendicitis. A critical review of diagnosis and treatment in 1,000 cases. Arch Surg 1975;110:677-84.

5. Izbicki JR, Knoefel WT, Wilker DK, Mandelkow HK, Müller K, Siebeck $\mathrm{M}$, et al. Accurate diagnosis of acute appendicitis: a retrospective and prospective analysis of 686 patients. Eur J Surg 1992;158:227-31.

6. Puylaert JB. Imaging and intervention in patients with acute right lower quadrant disease. Baillieres Clin Gastroenterol 1995;9:37-51. [CrossRef]

7. Hwang ME. Sonography and Computed Tomography in Diagnosing Acute Appendicitis. Radiol Technol 2018;89:224-37.

8. Evrimler S, Okumuser I, Unal N. Computed Tomography (CT) Findings of a Diagnostic Dilemma: Atypically Located Acute Appendicitis. Pol J Radiol 2016;81:583-8. [CrossRef]

9. Ceydeli A, Lavotshkin S, Yu J, Wise L. When Should We Order a CT Scan and When Should We Rely on the Results to Diagnose an Acute Appendicitis?. Curr Surg 2006;63:464-8. [CrossRef]

10. Teo AT, Lefter LP, Zarrouk AJ, Merrett ND. Institutional review of patients presenting with suspected appendicitis. ANZ J Surg 2015;85:420-4. [CrossRef]

11. Parks NA, Schroeppel TJ. Update on imaging for acute appendicitis. Surg Clin North Am 2011;91:141-54. [CrossRef]

12. Smith MP, Katz DS, Lalani T, Carucci LR, Cash BD, Kim DH, et al. ACR Appropriateness Criteria ${ }^{\circledR}$ Right Lower Quadrant Pain--Suspected Appendicitis. Ultrasound Q 2015;31:85-91. [CrossRef]

13. Birnbaum BA, Wilson SR. Appendicitis at the millennium. Radiology 2000;215:337-48. [CrossRef]

14. Pinto Leite N, Pereira JM, Cunha R, Pinto P, Sirlin C. CT evaluation of appendicitis and its complications: imaging techniques and key diagnostic findings. AJR Am J Roentgenol 2005;185:406-17. [CrossRef]

15. Pinto F, Pinto A, Russo A, Coppolino F, Bracale R, Fonio P, et al. Accuracy of ultrasonography in the diagnosis of acute appendicitis in adult patients: review of the literature. Crit Ultrasound J 2013;5:S2. [CrossRef]

16. Partrick DA, Janik JE, Janik JS, Bensard DD, Karrer FM. Increased CT scan utilization does not improve the diagnostic accuracy of appendicitis in children. J Pediatric Surg 2003;38:659-62. [CrossRef]

17. Karabulut N, Kiroglu Y, Herek D, Kocak TB, Erdur B. Feasibility of low-dose unenhanced multi-detector $\mathrm{CT}$ in patients with suspected acute appendicitis: comparison with sonography. Clin Imaging 2014;38:296-301. [CrossRef] 


\section{ORİJINAL ÇALIŞMA - ÖZET}

\section{Akut apandisit tanısında cerrahın BT'yi etkin kullanımı \\ Dr. Mehmet Mahir Fersahoğlu, Dr. Hüseyin Çiyiltepe, Dr. Anıl Ergin, Dr. Ayşe Tuba Fersahoğlu, Dr. Nuriye Esen Bulut, Dr. Ahmet Başak, Dr. Bora Karip, Dr. Birol Ağca}

Fatih Sultan Mehmet Eğitim ve Araştırma Hastanesi, Genel Cerrahi Kliniği, İstanbul

AMAÇ: Akut apandisit (AA), halen genel cerrahi acilleri arasındaki önemini korumaktadır ve bir insanın hayatında AA gelişme riski, erkeklerde \%8.6 ve kadınlarda \%6.7'dir. AA'nın klinik tanısı yaklaşık \%20 yanlış pozitif ve yanlış negatiflik oranına sahiptir. Görüntüleme yöntemlerinden de bu alanda en çok ultrason (US) ve bilgisayarlı tomografiden (BT) faydalanılmıştır. Bu çalışmanın amacı AA tanısı amacıyla çekilen kesitsel görüntüleme incelemelerinin değerlendirmesinde hastayı muayene eden klinisyenin değerlendirme sonuçları ile radyoloji uzman değerlendirmesi arasındaki ilişkiyi saptamaktır.

GEREÇ VE YÖNTEM: Bu çalışmada Ocak 2010 ile 2017 tarihleri arasında, Fatih Sultan Mehmet Eğitim ve Araştırma Hastanesi Genel Cerrahi Kliniği'nde apendektomi yapılan I89I hastanın dosyası geriye dönük olarak incelendi. AA kliniği ile apendektomi yapılan ve BT sonuçlarında apendiks normal olarak rapor edilen hastaların dosyasından, hastanın acil servise başvurusundaki klinik muayene bulguları ile birlikte ilgili cerrahın BT değerlendirme sonuçları (AA ile uyumlu, normal apendiks veya apendiks görüntülenmedi) kayıt edildi.

BULGULAR: Akut apandisit şüphesiyle apendektomi yapılan I89I hastanın I478'ine tanı amacıyla BT çekildi ve I45'i radyoloji uzmanları tarafından normal olarak rapor edildi. Radyoloji uzmanları tarafından tamamı normal olarak rapor edilen bu BT sonuçlarının cerrahlar tarafından yapılan değerlendirmesinde I05'i (\%72.4) AA ile uyumlu bulunurken, I8'i (\% I2.4) normal olarak değerlendirildi. Yirmi iki (\%।5.2) hastada cerrahlar tarafından apendiks vizüalize edilemedi. Patoloji sonucu lenfoid hiperplazi - fibröz obliterasyon gelen olguların \%70.0'i; AA sonucu gelenlerin \%73.8'i; Flegmenöz apandisit sonucu gelenlerin \%75.6'sı ve gangranöz/perfore apandisit sonucu gelenlerin ise \%64.0'ü genel cerrah tarafından yapılan BT değerlendirmesinde apandisit tanısı almıştır.

TARTIŞMA: Hastanın klinik değerlendirmesini yapan cerrah tarafından yorumlanan BT sonucunda tanısal doğruluk oranları belirgin bir şekilde artmaktadır. Genel cerrahi uzmanlık eğitimi sırasında abdominal kesitsel görüntüleme tekniklerini yorumlayabilme yetisi kazanılmasıyla birlikte doğru tanıya ulaşma şansı artacaktır.

Anahtar sözcükler: Akut apandisit; akut batın; bilgisayarlı tomografi.

Ulus Travma Acil Cerrahi Derg 2021;27(I):43-49 doi: 10.14744/tjtes.2020.13359 